\title{
Denotative and Conotative Meanings of Panasuan Language: Minor Language Conservation Efforts in West Sulawesi
}

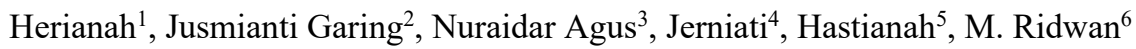 \\ \{herianah606@gmail.com¹, garingjusmianty@yahoo.co.id ${ }^{2}$, nuraidaragus777@gmail.com ${ }^{3}$, \\ jernihatiku@gmail.com ${ }^{4}$, hastianahnurdin@gmail.com, ${ }^{5}$ ridwan_egu@yahoo.co.id $\left.{ }^{6}\right\}$ \\ Balai Bahasa Provinsi Sulawesi Selatan $1,2,3,4,5,6$
}

\begin{abstract}
People speak the Panasuan language in the northern part of Kalumpang District and the western part of Seko District, Mamuju Regency, West Sulawesi Province. The Panusuan language is distinct from the other languages spoken on West Sulawesi. This distinction exists in the semantic aspect, particularly in denotative and connotative meanings. The research aims to express the denotative and connotative meanings of Panasuan language. The technique used is descriptive-qualitative, with listening, engaging, and notetaking. Data analysis includes the steps of identifying, selecting, classifying, and presenting data. The findings revealed that the Panusuan language requires a figurative meaning other than what it currently has. Some figurative meanings are found in this research, and those figurative can have two meanings; it depends on the sentence that follows them. The findings of this study are significant in expanding the knowledge for observers of regional languages in the archipelago and one of the efforts to preserve regional languages in Indonesia.
\end{abstract}

Keywords: denotative; connotative; Panasuan; preservation

\section{Introduction}

Language serves as a form of soul expression, a medium for expressing existence (selfexistence), emotional stress relief, and attracting the attention of listeners and readers [1], [2]. It is vital to conduct studies in language to implement human expression in communication based on this function. A study in the discipline of semantics is one of the studies under question. The semantic field is concerned with the study of meaning or semantics can be interpreted as an investigation of meaning in a language [3]. Semantics is a discipline of linguistics dedicated to exploring the linguistic meaning and interpreting expressions in the language system, according to [4]

Furthermore, semantics is defined by [5] as symbols or signals that express meaning, the relationship of one meaning to another, and its impact on persons and society. As a result, semantics encompasses the meanings of words, as well as their evolution and modifications. The definition of words is one of the essential characteristics of language. Accoding to [6], [7] 
and [8] a meaning of the word is separated into two parts: denotative and connotative. Denotation, on the other hand, is defined as the interpretation of a word or a set of words based on a specific performance on anything outside of the language or on certain norms, as mentioned by [9]. There are two relations in denotative meaning: the relationship between the word and the object. It represents the relationship between the word and the object's character or characteristics [10]. Its definition is in line with the opinion [11], [12], and [13]. Words that have denotative meaning are used by an author not to cause other interpretations from the reader. Denotative meaning is meaning by the results of observations according to sight, smell, hearing, feeling, or different experiences or called the meaning in accordance with what it is. Next is the meaning of connotation. Connotation is defined as a word or a set of words based on the speaker's (writer's) or listener's feelings or thoughts. The connotative meaning is then interpreted as creating the second layer of meaning. It is formed when feelings, emotions, and beliefs are all linked to the denotative sign. It has a close relationship with culture, knowledge, and history [14] and [15]. In other words, the connotative meaning is a word that has an emotional meaning. Furthermore, almost the same statement was put forward by [11] that the author uses connotative meaning to cause excessive feelings of something. A word is said to have a connotative meaning if it has "taste value," both positive and negative [16].

[5] states that linguistic meaning is divided into two types, namely denotative and connotative meaning. The denotations of a word are 'general, traditional, and precedent' meanings. The denotations are usually the result of centuries of using words; they end up in the dictionary and change a long way. On the other hand, connotations that are often personal emotional responses occur in most lexical words in most users. The genuine meaning is frequently expanded or stretched in conjunction with the connotative meaning, giving the term a new purpose or implying a new sense. As opposed to denotation, the connotation is a word that contains a circle of ideas and feelings that surround the word. We can see the difference between denotation and connotation in the synonyms of a particular word.

Examining the words of the Panasuan language will show how one word can have both meanings. The use of the term will appear to be dependent on the context of the sentences that make up the word in this example. Like the word 'flower' in Indonesian, it has two meanings, namely denotative and connotative. The word flower in a denotative sense means the part of the plant that will become a fruit, usually beautiful in color and fragrant in smell; flower, while flower in connotation can tell village girl or village flower. Likewise, in the Panasuan language, it will be seen how the use of denotative and connotative meaning differs in explaining the sentence.

The Panasuan language is one of the minor languages in Indonesia. The people who live in the northern half of Kalumpang Subdistrict and the west of Seko District, Mamuju Regency, West Sulawesi Province, speak this language. This language covers Malay-Polynesia [17]. The word Panasuan is composed of two words: Pana, which means 'Buru,' and Suan, which means 'location.' Thus, Panasuan refers to a hunting location. The Panasuan also means 'all available' about food because Southern means vegetables or food [18]. According to the information gathered, there are around 750 Panasuan speakers. The SIL believes that only about 800 people speak the language, which is not far off (SIL, 2000) in [19]. According to [19], roughly 1000 people talk about the language in the hamlet of Sandapang Village and neighboring villages in Kalumpang District. In West Sulawesi, this language is a minority language, and the threats to Major are Mandar and Mamuju.

The Kalumpang sub-district is challenging to navigate. It must travel in a car vehicle across a distance of about 100 kilometers from Mamuju. Then, against the tide, proceed on the river path in a tiny boat. It arrived in the village of Tambing-Tambing after a one-hour journey 
across the river currents. It then continued using two-wheeled vehicles since the terrain was rugged, which was only one way. After that, we arrived in the Panasuan settlement, which was highly modest (interview with Darius Timonga, 2019). Children, teenagers, and parents continue to use this terminology. They use this language to express their thoughts, feelings, and messages in writing and orally.

The findings of research into the Panasuan language are still uncommon. According to the author's understanding, the research done was "Kosakata Dasar Bahasa Panasuan serta Tata Bahasa Ringkas Bahasa Panasuan" authored by Manda, Yamaguchi, M, and Nakashima, H, in 2002 [18]. [19] published another study titled "Morfologi Nomina Bahasa Panasuan." Then, in 2015, [17] reworked "Karakteristik Fonem Bahasa Panasuan di Sulawesi Barat." According to the description, no previous research has been doing regarding denotative and connotative meanings. As a result, the authors performed this research to understand better the language of enthusiasm as one of the Indonesian people's strengths. So, the issue in this research is how the form of denotative and connotative meanings of the Panasuan language? The project then attempts to collect data and descriptions of denotative and connotative meanings in the Panasuan language, spoken as a local language in West Sulawesi Province.

\section{Method}

This study uses a qualitative method. Qualitative approaches are used to comprehend and interpret the significance of a human behavior interaction occurrence in a specific scenario. [20] [21], [22]. Furthermore, It was discovered that "qualitative research" refers to data collected in a natural situation. It was according to opinion [23], [24], [21]. Data was gathered directly from the subject's daily activities in the real world [25]. The qualitative research method is founded on postpositivism's theory and is used to investigate the state of natural objects (rather than experimental) and researchers as a critical tool [14], [26], [27]. Data collection was carried out using the participatory observation method, namely being at the research location and observing the language behavior of the speech community, which is used as the object of research, then recording examples of language use [28], [29]. When providing or collecting data, the researcher uses the listening method with basic tapping techniques, advanced techniques in free listening and conversational practices, and note-taking strategies. This technique is used in this study because in providing data, the researchers only act as an observer of the language spoken by the informant. In this case, researchers were not native speakers of the target language; they merely listened to the informants' use of language. In addition, the researcher also acts as a data collection tool or research instrument [30], [31], [32]. In this case, the researchers conducted a question and answered session with the informants and then recorded things related to the research substance, specifically about the meaning of denotation and connotation in the Panasuan language.

\section{Results and Discussion}

\subsection{Results}

3.1.1 The Denotative Meaning of the Panasuan Language 
The denotative or conceptual meaning, or superficial meaning, is the meaning that demonstrates the relationship between the notion and the world of reality. The following are some instances of denotative substances in the Panasuan language:

1a. Cristin ne'mehine ung makassing ene desanna (Cristin is a beautiful woman in her community). The first sentence (1a) has a denotative sense. The word makassing ' beautiful' is understood is in the dictionary; the term has a denotative meaning in this circumstance.

2a. Ene lempoku aha cindoang manini ung kandingan ma'kuru (There is a small study room for study in my house). The phrase cindoang manini, 'small room' in a sentence (2a), also has a denotative connotation. The little room in this statement is a study room or a small room utilized for that purpose.

3a. Amangku lulung mampilongkoking bu'una hamai nyarang (My father is slamming from the horse). A term with a denotative meaning appears in a sentence (3a), namely mampilongkaking 'slamming' a bone from a 'horse' nest animal. The true meaning has included in (3a) in this example.

4a. Andi na'kana maho ilaloing sikolanna (At school, Andi is a dunderhead). The term maho ilaloing, which means " dunderhead," appears in a sentence (4a), implying that receiving instruction at school is foolish. It explains the actual object; this sentence carries denotative meaning. The term school precedes it; it appears evident that the word stupid relates to what it signifies. Thus, the reference's purpose is consistent with its surroundings.

5a. Lempangko ene lempoku mulena (the afternoon, come over to my house for a while). For example (5a), the word lempoku, 'my house,' has a denotative connotation. The true meaning of lempoku is 'my house,' which refers to where people reside. There is a bedroom, a dining room, and a bathroom, among other things.

6a. Adi mampalao ising lumao mesame (Adi requested permission to defecate). In example (6a), the term mesame ' defecate' is used in a sentence with a denotative sense. It is an accurate term with real meaning. Adi begged for permission because he needed to defecate urgently, but he used the real purpose, making it appear impolite. As a result, the meaning of the phrase (6a) is denotative.

7a. Aha buhiki mangande balesu mate (A cat is eating a dead rat). There are denotative and real meanings in example (7a). The term balesu, which means 'rat,' is used in this sentence. The term balesu 'rat' in the above statement refers to a cat consuming a rodent, namely a rat. Rats are well-known for being filthy creatures who frequently end up as cat food. As a result, sentence (7a) is denotative.

8a. Ari' lulung mangande punci (Ari eats a banana). A denotative meaning seems in a sentence (8a). The verb mangade, which means 'eat,' contains this concept. Mangade is derived from the verb ande, meaning 'eat' as in 'to put something in one's mouth and chew it.' The key to 'banana' in a sentence (8a) is the food eaten. In this case of the accessible referents, it is apparent that the word ande 'eat' has a denotative meaning.

9a. Matama kayakna tek nabasa uhang (His clothes were wet by rain). There is a denotative or actual meaning in the phrase (9a), which is the word matama, which means 'wet.' Exposure to water or other liquid things may have made you wet in this situation. As a result of the rain, the garments are damp. Thus, there is a denotative or literal meaning in this sentence.

10a. Ama mangalli esongngang hou (Father bought a new chair at the shop). In phrase (10a), there is a sentence with a denotative meaning, which is the term esonggang, which means 'chair.' The genuine essence of a chair is an object that is used to sit; there are 
chairs made of wood, iron, bamboo, plastic, and other materials. On this occasion, the father purchased a brand new chair.

11a. Naina mangalli sassing bulahang macimminna sampulo grang (Mother purchased a tengram gold ring). There is a denotative meaning in the phrase (11a), the word bulahang, which means "gold." In this scenario, the fundamental meaning of gold is that it is a valuable precious metal. The meaning of gold that my mother purchased at the store, weighing ten grams, is contained in the preceding statement. Gold is currently priced at Rp. 500,000 per gram, making it a costly commodity.

12a. Cumbo ung napassadia cupa'balu bupirikmo ung yusuk (rice served by the vendor turned out to be stale and stinky). The sentence (12a) has denotative or literal meanings as defined by the dictionary. In this situation, the word 'stale' has a biblical meaning. In the passage above, bupirik'stale' refers to ruined and odorous food. So, the meaning of the preceding sentence incorporates denotative meaning.

13a. Anringku mampahoa pisang mambobok hangkakna (My sister enjoys biting her fingers). The phrase mambobok hangkakna, which originates from mambobok, means 'biting the finger' in a sentence (13a). In this example, the word bobok 'bite' refers to the act of putting something into one's mouth and biting it. Biting is a nasty habit that some people have. In the preceding sentence, the sister who has a propensity of biting her finger is mentioned. Thus, sentence (13a) is contained in a denotative sentence.

14a. Holiki mancibe lambakmo ese-ese (Don't throw rubbish around). The word mancibe 'throw away' appears in a sentence (14a) and has a denotative or actual sense. In phrase (14a), the term mancibe 'throw' refers to pour waste carelessly. As a result, sentence (14a) has a denotative meaning.

15a. Kangkangna Ali nabasa api, tek pangino api (While playing with fire, Ali's hand caught fire). A sentence has a denotative or actual meaning (15a), particularly the phrase pangino api 'playing with fire.' When Ali is playing with fire, whether it's burning wood or playing pyrotechnics, his hand gets sparks. When Ali's hand burns, he feels discomfort.

16a. Diana ma'lamung bunga ene pano halaman lempona (In her front yard, Diana planted flowers). There are terms in a sentence (16a) that have denotative or dictionary definitions. 'Flower' is the word in question. The flower in this example refers to a type of plant that is often grown in the ground and produces brightly colored blossoms. Some flowers are grown in containers, while others are planted directly in the background. Some flowers, such as jasmine and tuberose, can also generate a fragrant perfume.

17a. Bele makoro cio maroko (The black sheep is skinny). There is a denotative meaning in the phrase (17a), bele makoro 'black sheep,' which refers to a slender black sheep. Thus, the scapegoat in the preceding line has genuine meaning.

18a. Meja maliholong cio mahaba te' nalambi uhai (The flood damaged the green table). There is a denotative sense in a sentence (18a), namely the meja maliholong 'green table,' which means a green table. The table is frequently utilized as a storage area or a place to eat compared to a sentence (18b).

19a. Tau cio kisai tek nababo asu bombing (That person is fed up with being bitten by a vicious dog). There is a word in example (19a) that has both denotative and actual meanings. The denotative meaning is the term asu 'dog,' which refers to a four-legged, non-wild animal. This animal was once a human pet who served as a house guard. In this line, a person becomes ill after being bitten by a rabid dog whose saliva includes rabies and is harmful to people. 
20a. Essongngang malea papiande lombi mabo (The red chair wholly burned). The term papiande, which means 'burned,' is denotative meaning in example (20a). In the context of the statement above, papiande refers to something that is on fire. This sentence refers to an object, specifically a crimson chair that is being scorched by fire. As a result, sentence (20a) is a sentence with denotative meaning. In comparison to a sentence (20b).

21a. Darius aha mesa sapi mulea (Darius owns a herd of dairy cows). A phrase with a denotative meaning, namely cow sapi mulea 'dairy cow', appears in a sentence (21a). In this example, the term "dairy cow" refers to a female cow with milk for human use. This type of cow produces milk that is both healthful and beneficial to humans.

22a. Bu mobo iuru dai kamar (A scorched odor fills the space). The word mobo, which means 'scorched,' appears in a sentence (22a). The term 'scorched' in the preceding sentence refers to the object that has been burned to the ground, and it generates a foul odor. The meaning of the phrase (22a) boils and causes a scent that others can detect in the room.

23a. Inangku mangsimpo cumbo aringku (My mother bribed my sister's rice). A denotative meaning, notably the meaning of bribing 'mangsimpo,' can be found in the phrase (23a).

\subsubsection{The Connotative Meaning of the Panasuan Language}

A word or set of words with connotative meaning or figurative meaning is dependent on the speaker's (writer's) or listener's or thoughts (reader). Several examples have examined the denotative or conceptual meaning (1-23) a. It can compare to the climate in the example (1-23). The following example illustrates the connotative or figurative meaning.

1b. Tini tau mehine ung makassing kalena (Tini is a sweet woman). In sentence (1b), a word has a connotative meaning, namely the makassing 'sweet.' A woman is said to be stunning if she has a charming face and is generally liked by men. In this case, the word makassing is a woman who can also be said to have a look that wants to be 'sweet.' Sweet in this sentence does not mean the taste is sweet like food, but rather her beautiful face. Thus, sentence (1a) has the true meaning of beauty, while sentence (1b) has the meaning of beauty which is not authentic or has a connotative meaning.

2b. Ene lempoku aha kandingan mesame (There is a restroom or toilet in my home). In sentence (2b), a phrase contains a connotative semantic meaning, namely the kandingan mesame' restroom ' or 'toilet.' The phrase kandingan mesame means a room for defecation such as urinating, bathing, or washing clothes. Thus, in sentence (2a), the term cindoang manini 'small room' has a denotative meaning, whereas the phrase kandingan mesame 'toilet' in sentence (2b) has a connotative meaning. Compare and contrast the sentences below.

3b. Amangku ma'jama ma'cimi hasi (My father is working hard). The term ma'cimi hasi, which means 'working hard,' appears in a sentence (3b) to work as hard as possible to get more money. Furthermore, the term stupid in a statement (4a) compared to the word stupid in the following sentence has a connotative meaning (4b).

4b. Kale do'o nakana ung kale bengo (You're a silly boy, huh?) In example (4a), the term maho ilaloing 'silly or stupid' has a denotative meaning. This term is commonly used to emphasize the commonality of meaning, implying that they both have a low cognitive level. However, in the phrase (4b), the word bengo, which means 'dumb or silly,' has a more particular connotation, referring to less clever youngsters despite being taught the same thing repeatedly.

5b. Lempangko ene hasangku mulena (Come to my hut for a while in the afternoon). For example, (5b), a term, hasangku 'my hut,' has a connotative connotation. Although the 
words hut and house have identical meanings, the word hasang 'hut' is frequently used to humble oneself, even if the house is substantial. As a result, the hut's meaning (5b) incorporates a connotative connotation.

6b. Tabe, koi kopano kebo dolu, Pak! (Excuse me; I'll go back the first, Sir!). The term kopano kebo 'go back' appears in sentence (6b) and has a connotative sense. This expression is a metaphor for someone who needs to urinate, either to pee or to defecate. The word kopano kebo, which means 'go back,' is used to modify it. As a result, sentence (6b) has a figurative or connotative meaning.

7b. Ung jadi balesu ilaling kantor kai, ternyata tau ilaling (In reality, it turns out that the rat in our office is an insider). In sentence (7b), there is a word with a connotative meaning, namely the word balesu 'rat.' In this sentence, the balesu 'rat' is depicted on a person who is a corruptor or thief of office or company money. The word balesu 'rat' in a sentence (7b) has a symbolic meaning. Thus, this sentence includes sentences that contain connotative meanings.

8b. Sahona na 'kana' naande cura'a (His men's honor is also eaten). Sentence ( $8 \mathrm{~b}$ ) contains a connotative or figurative meaning in the word ande' eat.' This word means taking something that is not rightfully his. The connotative meaning of ande in the sentence ( $8 \mathrm{~b})$ implies that the leader also takes the honorarium of a subordinate. So, not the actual meaning but the symbolic meaning. Thus the word ande 'eat' in the sentence above has a connotative meaning. Compare the use of the word matama 'wet' in the following sentence $(9 b)$.

9b. Ari ma 'jama ene kindingan ung matama (Ari works in a wet environment). A term with a connotative meaning appears in a phrase (9b), matama, which means 'wet.' In this line, the term "wet" has a different meaning: it refers to a place or job that pays well. As a result, matama 'wet' has a connotative connotation in this statement.

10b. Amangna mallambi esongngang DPRD Mamuju (His father got a chair as a member of the DPRD Mamuju). Sentence (10b) has connotative meaning, i.e., it has symbolic meaning. The word esonggang, which means 'chair,' has a symbolic connotation in the line above, namely posture. As a result, the definition of the chair in the preceding sentence has a connotative connotation. In contrast, consider the following sentence (11b).

11b. Koi mampohoa pisang kamaha bulahang pinaninna (I adore the golden voice of the singer). Words with connotative or figurative connotations appear in a sentence (11b). In this context, the word bulahang translates to 'golden,' which has a connotative sense of a good or musical voice. As a result, the gold mentioned in the preceding statement has no bearing on the meaning. As a result, the connotative meaning of the phrase (11b) can be shown.

12b. Masalana tek bupirikmo jadi ikalempangimo tau (His problem is stale, so people have forgotten). In a statement, the connotative or figurative meaning is also present (12b). The term bupirik 'stale' refers to something that has been around for a long time; it has thus been forgotten. As a result, the statement (12b) has a connotative or figurative meaning.

13b. Ari lumao mambobok hangkakna (He returned home, biting his finger / disappointed, to no avail). The bobok hangkakna phrase 'biting the finger' is used in a sentence (13b) and connotative or figurative connotations. In the passage above, the term bobok hangkakna 'biting the finger' is taken as dissatisfaction. In this scenario, Ari is disappointed because he might have been seeking a job for days. Ari, on the other hand, returned home with no results other than biting his finger. 
14b. Holiki mancibe alomu (Do not waste your time). A word with a connotative or figurative meaning appears in the phrase (14b): mancibe, which means 'waste.' This word has a metaphorical sense, which means not being efficient with one's time. Thus, the connotative or figurative meaning of this sentence is included. Take a look at the examples below.

15b. Holi'i pangino api, ele malalangko na ande api (If you don't want to get burned, don't play with fire). There are phrases in a sentence (15b) that have connotative or figurative connotations. It is reflected in the pangino api 'play with fire,' which refers to engaging in an activity that has the potential to do injury to oneself. In this circumstance, people are forbidden from approaching other people's problems not being drawn into other people's difficulties. That's what it's referred to as "play with fire."

16b. Diana aha bunganna ene desanna (Diana is the village's flower). Compare and contrast example sentence (16b) with example sentence (16a). The word bunga 'flower' in a sentence $(16 \mathrm{~b})$ has a connotative or figurative sense. The term flower refers to a rural flower or a lovely young lady compared to a flower in this usage. Diana was thus the village's most attractive young lady. Compare and contrast the following sentence (17b) to the preceding sentence (17a).

17b. Dio mambabe koi menteng bele makoro (He used me as a black goat). If the term bele makoro is denotative in a sentence (17a), it is connotative (17b). In this line, the term bele makoro 'black goat' (17b) refers to the problem's perpetrator or cause.

18b. Kasisalang ibana pano meja maliholong (The case took to the green table). There is a connotative or figurative term in a sentence (18b). It is reflected in the word meja maliholong 'green table,' which refers to a court or a venue for fairly resolving disputes. As a result, the connotative meaning of a sentence (18b) is clear.

19b. Dasar dio asu, nabisako dipatongan (I can't trust you, the dog you, lol). Connotative meaning is also present in a sentence (19b). It can find in the word $a s u$, which refers to a four-legged animal commonly kept as a housekeeper (compare the example sentence 19a). However, in sentence (19b), the term asu carries a filthy connotation. Typically, the word dog conjures up images of greedy, untrustworthy individuals. As a result, the meaning of the sentence $(19 \mathrm{~b})$ is connotative or figurative.

20b. Pinahananna papiande mampasihoi sangnginahanna subaha mehine senga (His heart is flaming with resentment when he sees his sweetheart with another girl). The word with connotative or figurative connotations finds in a sentence (20b). The word papiande, 'flaming,' connotative sense of a fiery heart, refuses to accept, resulting in jealousy. In this example, a man is envious of his lover since she walks with another woman.

21b. Dia menteng sapi mulea ene kanto (In the office, he's like a cash cow). The phrase sapi mulea 'cash cow' appears in a sentence $(21 \mathrm{~b})$, and it refers to people who are constantly told to work hard by their bosses. The task was only allotted to one person, resulting in that person's workload becoming many and piled up. Dairy cows are the term for persons like this. Thus, sentence (21b) has a connotative meaning.

22b. Doina mobo ene bank (His funds have been forfeited in the bank). The word mobo, which means 'forfeited,' has a connotative meaning in a sentence (22b). In phrase (22a), the term burned has a different meaning than in sentence (22b), lost or vanished. As a result, the meaning of the phrase $(22 \mathrm{~b})$ is connotative or figurative.

23b. Cio mangsimpo kapala desa (He bribed the village head). There is a connotative meaning in the phrase (23b), especially the word mangsimpo, which means bribing someone to make all of their affairs simpler. 


\subsection{Discussion}

Words found in the results of this study are described as the denotative and connotative meaning of the Panasuan language. Those words are discussed in-depth, like makassing 'beautiful,' mahuo 'sweet,' cindoang manini 'small room,' maho ilaloing 'stupid,' bengo 'stupid,' lempoku 'my house,' hasang 'gubuk,' kopano kebo 'backward,' balesu 'rat,' mangande 'eat,' pangino api 'playing with fire,' bele makoro 'scapegoat,' ande 'eat,' papiande 'burned,' and mangsimpo 'bribe.' Furthermore, the meaning arising from the words is a distinguishing feature of denotative and connotative meanings for other languages, especially regional languages in Indonesia.

The denotative or conceptual meaning that shows to the words in the Panasuan language has the relationship between the concept and the world of reality, or straightforward meaning, meaning as it is. Denotative meanings which appear are the actual meaning that refers to the notion and the world of reality. In addition, the actual meanings indicate the impolite words in the Panasuan language. It means that the terms that arise in the words of the Panasuan language are in accordance with the real meaning as in the dictionary. It is formed from smell, hearing, feelings that are linked to the denotative sign. This finding is connected to the results of research mentioned by [11], [12].

On another side, connotative meaning or symbolic meaning found in the Panasuan language is a word or group of words based on feelings or thoughts that arise or are caused by the speaker (writer) and listener (reader). Connotative words are also named figurative meanings. In addition, words in the Panasuan language have a metaphorical sense, which means not being efficient with one's time. Another finding is the connotative meaning in the Panasuan language is creating the second meaning, or the genuine meaning is frequently stretched or giving a new purpose or implying a new sense. The discussion is related to the theory conveyed by [14] and [15].

In the study, the denotation and connotation meanings of the Panasuan language appear to use the same word, or one word indicates both senses. In this case, the use of the word appears in the context of the sentence that builds the word.

\section{Conclusion}

The Panasuan language research focuses on the study's denotative and connotative meaning specialization, aims to preserve and document minor languages in West Sulawesi Province. In the form of reflections on the denotative and connotative meanings of the Panasuan language, the output can enrich Indonesia's scientific repertoire and serve as a reference for developing scientific knowledge of the language in particular. The Panasuan language still has a lot of room for improvement. New studies from various angles are planned to arise, resulting in more diverse local language documentation. Furthermore, it is intended that the findings of this work would be valuable to scholars in the field of semantics in particular and language observers in general.

\section{Acknowledgements}

Herianah is currently working at the South Sulawesi Language Center as an expert researcher. Her research entails applied linguistics, including Indonesian and regional languages, focusing 
on South and West Sulawesi. Jusmianti Garing is also an expert researcher specializing in linguistics, both theoretical and applied linguistics. Furthermore, Nuraidar Agus, an expert researcher. Interdisciplinary Linguistics is her area of specialization. Then, Jerniati I, a principal expert researcher, her research focuses on theoretical linguistics. As an expert researcher, Hastianah concentrates on Interdisciplinary Linguistic Studies, both in Indonesian and regional languages. M. Ridwan, as an assistant researcher is specializing in language and literacy acquisition.

\section{References}

[1] Emmy E. Analisis Perbedaan Makna Dasar Kata dalam Bahasa Indonesia dan Bahasa Malaysia. Sawerigading. 2021;1. DOI: https://doi.org/10.26499/sawer.v27i1.892

[2] Henry Tondo. Kepunahan Bahasa-Bahasa Daerah: Faktor Penyebab dan Implikasi Etnolinguistis. Masy dan Budaya LIPI [Internet]. 2009;11(2). DOI: https://doi.org/10.14203/jmb.v11i2.245

[3] Garing, Jusmianti. Analisis Semantik Cerita Lakipadada. Sawerigading, Vol 23, No 1, 2017. DOI: https://doi.org/10.26499/sawer.v23i1.188.

[4] Wahyudi, Resty; Sari SF. Makna Denotatif dan Konotatif pada Artikel Pos Jakarta. Sej (School Educ Journal). 2019;

[5] Tarigan HG. Pengajaran Gaya Bahasa. Bandung: Angkasa. 1986.

[6] Dahnilsyah. Connotative and Denotative Meaning of a Poem Entitled: Membaca Tanda-Tanda on Environmental Devastation: An Ecocriticism. In: Journal of Physics: Conference Series. 2020. DOI:10.1088/1742-6596/1655/1/012145

[7] Jumaniyazovich JA, Olimovna TD, Otabekovna IA. The Denotative And Figurative Meaning Relations Of The Components Of Word Combinations. Int J Progress Sci Technol. 2021; DOI: http://dx.doi.org/10.52155/ijpsat.v25.1.2821.

[8] Safarov FS, Istamova SM. Types of lexical meanings. Journal of Critical Reviews. 2020.

[9] Kridalaksana H. Kamus Linguistik. Jakarta: PT Gramedia; 2008.

[10] Keraf G. Diksi dan Gaya Bahasa. Duapuluh s. Jakarta: Gramedia Pustaka Utama; 2016.

[11] Wahyuningsih TM. Makna Denotatif dan Konotatif $<$ Em $>$ Hana $</$ Em $>$ (Hidung) pada Cerpen Â€Chanaâ€ $\square$ Karya Akutagawa Ryunosuke. Alayasastra. 2020;

[12] Sabriah. Makna Denotatif dan Konotatif dalam Gelong Pare Toraja. Sariwegading. 2011;

[13] Kalesaran EEP, Kalangi LMV, Salea-Warouw M. Makna Denotatif dalam Syair Tarian "Pomonte" Masyarakat Suku Kaili di Kota Palu. Kajian Linguistik. 2019.

[14] Juprinedi J, Siahaan AU, Miranto C. Analisis Makna Denotatif dan Konotatif dalam Film Upin \& Ipin Episode Kenangan Mengusik Jiwa. Journal of Digital Education Communication, and Arts (DECA). Vol 3, No 01.2020. DOI: https://doi.org/10.30871/deca.v3i01.1986

[15] Dash NS. Context and Contextual word Meaning. Skase J Theorotical Linguist [Internet]. 2008;5(2). Available from: http:/www.skase.sk./Volumes/JTL12/pdf doc/2.pdf

[16] DJajasudarma TF. Semantik II Pemahaman Ilmu Makna. Bandung: Eresco; 1999.

[17] Jerniati. Karakteristik Fonem Bahasa Panasuan di Sulawesi Barat. Sawerigading. $2015 ; 2$.

[18] Manda ML dkk. Kosakata Dasar Bahasa Panasuan serta Tata Bahasa Ringkas Bahasa Panasuan dan Kosakata Dasar Bahasa Tangkou serta Tata Bahasa Ringkas Bahasa 
Tangkou. Kyoto Japan: Nakanishi Printing.; 2002.

[19] Ed.Maknun T. Morfologi Nomina Bahasa Panasuan; Laporan Penelitian Bahasa Hampir Punah. Makassar: Garis Khatulistiwa; 2015.

[20] Usman H dan PSA. Metode Penelitian Sosial. Jakarta: Bumi Aksara; 2000.

[21] Rahmat PS. Penelitian Kualitatif. Journal Equilibrium. 2009.

[22] Mohr LB. The qualitative method of impact analysis. American Journal of Evaluation. 1999;20(1):69-84 https://doi.org/10.1177/109821409902000106

[23] Leeming P. RETROSPECTIVE DATA COLLECTION: CAN STUDENTS REMEMBER? Indonesian Journal Applied Linguistics. 2015; 4 (2), pp. 1--19. DOI:10.17509/ijal.v4i2.679.

[24] Ivanovich Agusta. Teknik Pengumpulan dan Analisis Data Kualitatif. J Stud Komun dan Media. 2014;

[25] Herianah H. Pengungkapan Makna Puisi "Bila Tomanurung Balik ke Langit" Karya Husni Djamaluddin. Gramatika J Ilm Kebahasaan dan Kesastraan. 2013;

[26] Chairina Nasir YQY, Wardana and A. A qualitative study of teacher talk in an EFL classroom interaction in Aceh Tengah, Indonesia. Indonesian Journal Applied Linguistics. 2019;8(3):525--535. DOI: https://doi.org/10.17509/ijal.v8i3.15251

[27] Chitsaz AT-EKC. A Classification of Qualitative Research Methods. Int J Educ Res. 2011;September(20):106--123.

[28] Nursyamsi T dan. Adaptasi Linguistik: Kasus Kontak Bahasa Antaretnik dalam Menciptakan Keharmonisan di Kabupaten Parigi Moutong. Sawerigading. 2021;1. DOI: https://doi.org/10.26499/sawer.v27i1.605.

[29] Gill P, Stewart K, Treasure E, Chadwick and B. Methods of data collection in qualitative research: interviews and focus groups. British Dental Journal. 2008;204(6):29-295. DOI:10.1038/bdj.2008.192.

[30] Nalita James. The use of email interviewing as a qualitative method of inquiry in educational research. Brtish Educational Research Journal. 2013; Januari(2). DOI:10.1080/01411920701657074.

[31] van der Burg, Jan; Jongerius, Peter; van Limbeek, Jacques; van Hulst, Karen; Rotteveel J. Drooling in children with cerebral palsy: a qualitative method to evaluate parental perceptions of its impact on daily life, social interaction, and self-esteem. International Journal Rehabil Res [Internet]. 2006;29(2):179-82. DOI:10.1017/S0012162206000235

[32] Lawrence J, Tar U. The use of Grounded Theory Technique as a Practical Tool for Qualitative Data Collection and Analysis. Electron J Bus Res Methods. 2013;11(1). 